\title{
Personal learning environments and university teacher roles explored using Delphi
}

\author{
Zaffar Ahmed Shaikh \\ Faculty of Computer Science, Institute of Business Administration Karachi, Pakistan \\ Shakeel Ahmed Khoja \\ Faculty of Computer Science, Institute of Business Administration Karachi, Pakistan
}

\begin{abstract}
This paper presents the results of research using an online Delphi method, which aimed to explore university teacher roles and readiness for learner-centred pedagogy, driven by personal learning environments (PLEs). Using a modified Policy Delphi technique, a group of researchers worked with 34 international experts who are university teachers by profession, but who are currently associated with PLEs as PLE-practising teachers, researchers, and developers. A questionnaire based on the relevant literature published between 2006 and 2012 was developed to serve the panel as the starting point for the Delphi debate. This questionnaire sought Delphi experts' consensus on the names and task descriptions of 36 university teacher roles categorized into five core competencies. During the three rounds of this study, the experts changed the names of many roles and modified their task descriptions. The study concluded by identifying the 28 roles on which the Delphi panel was able to reach a consensus. The results also revealed that the university teacher today is ready to carry out the new roles suggested by this study.
\end{abstract}

\section{Introduction}

A personal learning environment (PLE) is an individual's online learning space premised on the personalisation and openness offered by Web 2.0 tools and social media; a workspace which is conceptualised, built, and controlled by learners in their quest to become self-reliant, connected, and lifelong learners. In addition to this emphasis on personalisation, independence, and learner-centeredness, Dabbagh and Kitsantas (2011) note that a PLE is socially mediated knowledge and a networked learning platform which "help[s] learners aggregate and share the results of learning achievements, participate in collective knowledge creation, and manage their own meaning making” (p. 1).

Three approaches to PLE implementation are currently under discussion in PLE circles: (1) client-side locally based software program PLE, (2) server-side web browser services PLE, and (3) hybrid approach PLE (Archee, 2012). The client-side PLE allows learners to connect to online and offline learning resources through locally based client software (e.g., operating systems). The server-side PLE allows learners to connect to web servers and applications through web browsers (e.g., GRAASP, ELGG). The hybrid PLE, which already exists in the form of laptops and personal digital assistants, allows learners to use and store digital technology resources and devices how and where they want to.

The PLE concept is nowadays gaining popularity among higher education circles as the most realistic application of Web 2.0 technologies to education and a natural system for individuals to learn (Sharma \& Kawachi, 2012; Archee, 2012). This concept has emerged as a reaction to the limitations of learning management systems and as recognition of the interactive and learner-centred features of Web 2.0 and social media. According to Shaikh and Khoja (2012), the PLE concept is learner-centric (supporting personalisation and self-direction), holistic (bringing together both informal and formal learning landscapes in one place), and robust (quickly adjusting to the changing learning conditions). Attwell (2007) and Van Harmelen (2006) report that the PLE concept supports learners' self-regulation-learners are free to choose among many learning resources that best suit their current learning needs, allow them to control their learning, enable them to communicate with peers or more knowledgeable colleagues, and encourage them to attain their learning goals independently.

PLE-driven pedagogy effectively addresses the issues of personalisation and learner-centeredness, learner engagement and interaction, and provides a flexible framework for teaching and learning in the digital age (Häkkinen \& Hämäläinen, 2011). McRae (2010) proposes that PLE-driven pedagogy should not be considered only as a mechanical act of delivery of content and customisation, but rather as a socially 
constructed, active and inquiry-oriented process which engages learners in social, emotional, cultural, and deeply intrapersonal experiences. Recent research at the crossroads of PLE and learner-centred pedagogy suggests that university teachers should support their instructional approaches with the PLE concept and build a strong and multifunctional association between students' formal and informal learning spaces (Shaikh \& Khoja, 2012; Downes, 2011).

Häkkinen and Hämäläinen (2011) argue that a university teacher needs to support her students in developing meaningful learning environments, which provide them with ways of fulfilling their continuing learning needs. Drexler (2010) proposes that, based on a university teacher's understanding of the challenges her students face in exploiting Web 2.0 tools for learning, a teacher should support her students to develop a PLE. However, as Dabbagh and Kitsantas (2011) and Miliband (2006) report, in reality a university teacher's competencies for PLE-driven pedagogy have not reached a sufficient level to carry out this task. A major cause of this deficiency is the lack of awareness of the roles that the university teacher is expected to perform within such environments (Shaikh \& Khoja, 2012; Downes, 2011). This prompted the researchers to examine university teacher roles and readiness to ensure that students receive adequate PLE coaching.

Currently, the literature provides only a few studies which explore university teacher roles for PLE-driven pedagogy (see Shaikh \& Khoja, 2012; Dabbagh \& Kitsantas, 2011; Downes, 2011; Kitsantas \& Dabbagh, 2010). Therefore, the researchers deemed it appropriate to conduct a Delphi study to validate the results of earlier studies on this rather new but burning research topic and to explore any new insights about it. The study was guided by the following two questions:

1. The introduction of the concept of PLE to teaching and learning at the higher education level has led to a change in students' learning processes, learning styles, and pedagogies which are more learner-centred. What changes to the traditional roles and related competencies of university teachers are required to cater to this new situation?

2. To what extent is today's university teacher capable or ready of assuming the new roles that have been suggested?

In light of the questions above, this paper presents the results of a modified Policy Delphi technique which explored university teacher roles and readiness for PLE-driven pedagogy. The Delphi method is a collaborative problem-solving technique which has been used to solve new, vague, or complex problems. It allows a group of geographically dispersed domain experts to serve as a random sample of the community to solve emergent problems in their field without holding face-to-face meetings.

The paper is organised as follows: the next section discusses the research background describing PLEs within the higher education context, university teacher roles for PLE-driven pedagogy, and the justification for using Delphi method. The modified Policy Delphi method is then detailed in the methodology section. An explanation of how to interpret results is provided in the data analysis section. The results section portrays the final results set of this study followed by the limitations of the Delphi method. The conclusions section provides discussion on each of two questions posed. This section is divided into two more sections: the implications of the findings for future practice and policy and the recommendations for future research.

\section{Research background}

\section{PLEs within the higher education context}

Situating the PLE concept in teaching and learning at the higher education level raises some questions. These include: is the learning and behaviour of today's university students self-regulated? Should they need support to exploit Web 2.0 and social software as formal learning tools? Do they know what a PLE is? Do university students know how to use their PLE for social interaction, global participation, peer review, and content management? Do they know how to exploit their PLE to become autonomous, connected, and lifelong learners?

According to the research findings (see Sharma, 2012; Johnson, Adams, \& Haywood, 2011; Dabbagh \& Kitsantas, 2011), not all university students are independent learners. They do not possess self-regulated 
learning skills and knowledge management competencies sufficient to build a PLE that supports them in their learning adventures (McLoughlin \& Lee, 2010; Clark, Logan, Luckin, Mee, \& Oliver, 2009). According to Steele, Hamilton, and Stecher (2010) students need training, support, and pedagogical interventions to benefit from their PLE. Hemmi, Bayne, and Land (2009) suggest that a pedagogical shift towards learner-centred and collaborative modes of inquiry would prove to be an important intervention. Väljataga, Pata, and Tammets (2011) recommend that teaching strategies which instigate students to use advanced technologies in organizing their learning resources into meaningful learning activities need to be developed. Current research (see Väljataga et al., 2011; Dabbagh \& Kitsantas, 2011; Clark et al., 2009; Turker \& Zingel, 2008) has also suggested that effective PLE-driven pedagogy needs to be considered as an act of instructional design.

The PLE idea supports the merger of formal and informal learning environments. Several studies conducted within the higher education context (see Harrison, 2011; Smith \& Caruso, 2010; Hazari, North, \& Moreland, 2009; Clark et al., 2009; Hemmi et al., 2009; EDUCAUSE Learning Initiative, 2007) note the increased use of social media and Web 2.0 tools by students as well as by faculty members. Other studies (see Dabbagh \& Kitsantas, 2011; Dabbagh \& Reo, 2011; McLoughlin \& Lee, 2010; Drexler, 2010) report that the PLE-driven pedagogy is potentially a promising instructional approach and that higher education institutions should facilitate the building of PLEs to support more learner-centred and independent education systems. Whether considered as a technology that helps learners aggregate and share their learning resources or as a teaching and learning approach that fulfils learners' personal learning needs, the PLE concept is the most workable way of facilitating learners' interaction with and use of advanced digital technologies into learning (Archee, 2012; Verpoorten, Glahn, Kravcik, Ternier, \& Specht, 2010).

\section{University teacher roles for PLE-driven pedagogy}

University teachers' responsibilities at work have increased. They are expected to possess a diverse set of skills to perform both pedagogical and technological roles efficiently and effectively (Downes, 2011; McGee \& Fraser, 2011). Hargreaves and Shirley (2009) claim that besides scaffolding learners' reflection and developing their professional competencies, the free and easy availability of Web 2.0 tools has resulted in complex and multifaceted challenges for university teachers-including the support of PLEdriven pedagogy. The current research (see Shaikh \& Khoja, 2012; Dabbagh \& Kitsantas, 2011; Downes, 2011; McGee \& Fraser, 2011; Minocha, Schroeder, \& Schneider, 2011; Guasch, Alvarez, \& Espasa, 2010; Siemens, 2010) shows that PLE-driven pedagogy requires a university teacher to perform many extra roles in order to fulfil changing educational and learning needs. Some of the roles of the university teacher which are rather new but which have been repeatedly discussed in the literature include psychologist, innovator, agitator, salesperson, critic, technician, sharer, etc.

Siemens (2010) argues that the role of a university teacher in today's world, which is shaped by technological and social networks, (e.g., environments) is to model and influence a learning network for her students. He reports that in PLE, social and technological networks subvert the classroom-based role of teacher. The teacher, who is the most prominent node in learners' network, needs to support her students to develop their networked learning skills and to motivate them to become sophisticated networked learners. For PLE-driven pedagogy, Siemens suggests that the university teacher should perform the tasks of amplifying, curating, way finding and socially-driven sense making, aggregating, filtering, modelling, and persistent presence. He asserts that the network of information is shaped or amplified when a teacher's pedagogical practices (e.g., messages) draw students' attention to content elements. Explaining the role of curator, Siemens notes, "the curator includes critical course concepts in her dialogue with learners, her comments on blog posts, her in-class discussions, and in her personal reflections" (para. 17). The university teacher can aid the way-finding process of learners in PLE through consistency of design and functionality across various tools and offer them critical or antagonistic perspectives on their learning processes. Defining aggregation as means of making sense of the landscape, Siemens suggests that an aggregator should unfold the learning content and conversation structure to students only when it is needed rather than defining it in advance. Discussing the filtering task, Siemens posits that learning is an eliminative process and the university teacher should provide her students with one stream of filtered information at a time, and then move on to another stream. This practice would assist her students in determining whether such information belonged to their learning processes or not. Coining the term modelling from Downes's (2007) statement, "to teach is to model and demonstrate, to 
learn is to practice and reflect” (para. 49), Siemens proclaims that what a teacher cannot explain through lecture or through other teaching activities, the same can be addressed through modelling. The persistent presence requires the university teacher to have an online identity through which she can be found and contacted in time of need. A university teacher needs to have an online blog or a social networking profile in order to know others and to be known. He contends that a university teacher's online availability and persistent presence weaves a narrative of coherence with learners.

Reflecting upon his observations and experiences while working on increasingly advanced forms of online teaching and learning (i.e., MOOCs), Downes (2011) identifies 23 roles for the PLE-aware teacher. He notes that the university teacher is an agitator who "creates the seed of doubt, the sense of wonder, the feeling of urgency, and the cry of outrage" (para. 35) in her students, and is a critic who "asks for evidence, verifies the facts, assesses the reasoning, and offers opinions" (para. 39) to her students. Downes reports that PLE-driven pedagogy needs the university teacher to be a bureaucrat who collects and keeps students' records, provides them with statistics on their learning processes, manages the finances incurred in learning, tracks the services required by students during their learning endeavour, organizes accountability procedures to guide their learning, and maintains systematic coherence. In addition, Downes sees the university teacher as planner of the collaborative learning environment who allows her students to acquire knowledge collaboratively and socially through interacting with peers, mentors, and teachers; designer of students' learning plans who takes account of students' challenges to help them pace their learning and to achieve their desired goals; promoter of learners' autonomy, confidence and effectiveness in supportive learning environments; counsellor who establishes learning outcomes, validates knowledge acquired through collaborative learning, and assists learners to control their learning; and a guide who supports learners to develop, own and manage their learning environments.

Minocha et al. (2011) systematically conceptualize teacher roles in higher education and give a research agenda for social software-driven environments. They note that responsibilities of the educator "range from feedback on every student's contribution, regular interventions by the educator in the dialogue in discussion forums, and the educator being available to address any technical support queries that the students may have” (p. 9). Their research disentangles university teacher roles into a triad of behaviours, social positions and expectations following Biddle's (1986) core concepts of role theory. A university teacher's behavioural aspect (e.g., pedagogical, managerial and technical behaviours) encompasses monitoring of students' interactions and acting as an online role model. The social position and expectations (e.g., teachers' reputation in online communities and level of their relations with policy makers, supervisors, and technical support team) is an important characteristic of an educator which includes expanding students' social interactions and making PLE-building resources available to them. In addition to insights from Biddle's role theory, Minocha et al. recommend some more roles for the PLEaware teacher. These include facilitator who "initiate[s] and guide[s] the knowledge construction process among students"; technologist who "select[s], set[s] up, and maintain[s] the software tools for their students"; course designer who selects and matches "the pedagogy appropriate for the particular tools used"; and online role model who "demonstrate[s] their students appropriate forms of interaction in these environments" (p. 2).

Dabbagh and Kitsantas (2011) developed a three-level pedagogical framework for social media use in teaching and learning in higher education. Their aim was to assist the university teacher regarding how to engage students in a transformative cycle of PLE building. For this, they divided university teacher tasks into three levels: goal setting and planning, social interaction and collaboration, and information aggregation and management. At the goal setting and planning level, the university teacher motivates and encourages students to create their PLE by "self-generating content [from social media such as blogs and wikis] and managing this content for personal productivity or organizational e-learning tasks" (p. 4). At the social interaction and collaboration level, the university teacher performs the task of extending students' PLEs from personal learning spaces to social learning networks. In information aggregation and management level, she develops students' self-regulation skills and guides them on how to customize a PLE to achieve learning goals.

Shaikh and Khoja (2012) identify 36 roles of a university teacher in their PLE-driven pedagogy model. They divide university teacher roles into five core competencies which include: planning and design, instruction and learning, communication and interaction, management and administration, and use of 
technology. Planning and design competency encompasses developing students' PLE concept and supporting them to design adaptable and responsive learning environments. Instruction and learning competency covers the instructive and cognitive skills of a university teacher. Promoting students' relations with peers, other knowledgeable people, and mentors fall within the communication and interaction competency. The management and administration competency is about developing a university teacher's management skills. These include establishing the ideal environment for learning in the classroom, responding to students' expectations, and managing students' formal and informal learning practices. The technological competency covers general understanding of learning trends and technical knowledge of support services, and social, open access, and proprietary software.

Therefore, this study aims to validate university teacher roles as identified by these studies and to explore any new insights on this topic through the Delphi method.

\section{Delphi method: Building consensus on university teacher roles for PLE-driven pedagogy}

Delphi is a research-based collaborative problem-solving technique. It allows a group of geographically dispersed domain experts serving as a random sample of the community to solve emergent problems in their field without holding face-to-face meetings. Many features distinguish a Delphi probe from other survey or interview-based methods. These include the liberty to select a smaller number of participants; running the questionnaire over multiple rounds helps to reach a strong consensus; individual reporting of previous round's responses to each participant; avoiding the drawbacks of face-to-face debates; and respecting the minority view (Snelson, Rice, \& Wyzard, 2012; Shaikh \& Khoja, 2011). Achieving a high level of consensus is regarded as the most desirable objective of the Delphi method. In fact, as Na (2006) notes, the Delphi procedure should be fair enough to automatically reach a high level of consensus.

The Delphi method has three flavours distinguished by their intent. The Policy Delphi technique is for a situation when there is a need to devise a strategy to tackle a new or vague phenomenon which is caused by any compelling issue (Clayton, 1997). The Classical Delphi technique is used to forecast about the future (Shaikh \& Khoja, 2011). The Decision-making Delphi technique is used to reach conclusions that help in better decision making (Hasson, Keeney, \& McKenna, 2000). Today, modified Delphi investigations are very popular. These allow researchers to include open-ended questions, allow participants to give their input (suggestions, comments, addition, deletion of items), and are used in situations when stable results are also important besides achieving strong consensus (Hsu \& Sandford, 2007; Na, 2006).

Many researchers have used the Delphi method in education and educational technology. Shaikh and Khoja (2011) used a modified Classical Delphi technique to forecast future events. Brill, Bishop, and Walker (2006) used Policy Delphi to reach consensus on vague problems. And to gain a better understanding of current practices, research trends, and perceived obstacles, O’Neill, Scott, and Conboy (2011) and Pollard and Pollard (2005) found Decision-making Delphi an appropriate technique.

The PLE concept in higher education is a complex educational mix of Web 2.0 tools, the internet, and the resources provided by institutions. Its emergence in higher education invites university teachers and students to develop their PLE-driven teaching and learning skills. However, PLE-driven pedagogy is still a new and ill-defined phenomenon for many university teachers and administrators. They have no adequate knowledge of PLE and learner-centred pedagogy (Archee, 2012; McRae, 2010). Only recently has the literature started providing useful discussions on this burning issue of educational technology (Shaikh \& Khoja, 2012; Kitsantas \& Dabbagh, 2011). Thus, to develop the future research agenda and to establish facts about this new, complex, and ill-defined teaching and learning phenomenon, the researchers deemed the modified Policy Delphi technique to be most useful.

\section{Methodology}

The researchers used modified Policy Delphi technique to solicit experts' view on university teacher roles and readiness for PLE-driven pedagogy. An agreed and well-formed synopsis in the form of an online questionnaire was developed and brought forward for debate to Delphi participants. The participants comprised 34 university teachers from the areas of teaching, research and practice from different geographic regions of the world. This online Delphi study lasted for three rounds until it reached either 
some level of consensus or achieved stability on probed statements. The study revealed participants' collective view, indicating their perception of importance and level of consent with the statements in the questionnaire.

\section{Literature survey for the design of the questionnaire}

To serve as the starting point for the Delphi debate, a questionnaire was developed based on comprehensive analysis of the relevant literature published between 2006 and 2012. The literature review was guided by two theme questions listed in the 'Introduction' section. The researchers reviewed studies which highlight the need for faculty development for learners’ personalisation, learner-centredness, selfregulated learning, and PLE-driven pedagogy contexts. Studies on university teacher roles, competencies and readiness for online, distance, face-to-face and blended learning environments were also covered. This exercise identified 36 university teacher roles along with key task descriptions of each role. However, the search for literature on university teachers' readiness for PLE-driven pedagogy did not yield any results (the literature is silent on this topic). Prior to putting this questionnaire before the expert panel, the researchers pilot tested it on three experts available locally.

\section{Selection of experts}

Selection of domain experts, which is usually based on various characteristics, skills, and qualifications, is very critical for the success of a Delphi study. A purposeful and effective panel, as Na (2006) notes, "not only maximizes the quality of responses but also gives the results of the study credibility” (p. 31). Thus, the platform of The PLE Conference (http://pleconf.org/) was deemed appropriate to search the representative sample of the university teaching community who are associated with PLEs as PLE practising teachers, researchers, and developers.

The PLE conference platform was also used as a launch pad for dispatching the invitation to potential participants. Firstly, the on-site and the online attendees of the conference were invited personally by the first author of this paper while presenting their model of university teachers' PLE competency development (please see, Shaikh \& Khoja, 2012). Secondly, a total of 150 well-known university teachers of international repute, whose reputation was derived either from their publications or professional record of accomplishments, were invited through email invitations or Facebook chat messages. Thirdly and finally, to seek wide participation, the researchers broadcasted the Delphi invitation to the globally scattered anonymous PLE community through tweets, blogs or website entries, and Facebook posts. To explore a variety of views, the researchers paid particular attention to the representative sample from the teaching, research, and professional community of higher education with an interest in PLE-driven pedagogy. In response to these invitations, a total of 54 PLE experts pledged to participate in this Delphi.

Expertise has been considered to be the most important criteria for selection as a Delphi participant. Thus, for a person to qualify as a participant of this study, he or she should demonstrate a broad range of expertise in the PLE domain, such as job category, job designation, job industry, and work experience. Responding to current job category, of the 34 participants, 22 replied that they are PLE practising university teachers, six introduced themselves as PLE researchers at doctoral level, and another six participants were currently involved in PLE design and development activity. On the job designation scale, 15 members had the designation of faculty members, five were program managers or project directors, four indicated their job designation as department chair, and the remaining 10 were doctoral level research students. When asked to which industry their job is associated, 23 replied that their job industry was university or higher education, seven were working on projects with learning agencies, two were affiliated with education ministries, and the remaining two did not respond to this question. For work experience, nine indicated that they have been involved with PLE-driven teaching, research and development for more than 5 years, while two indicated less than one-year work experience. The Delphi panel included two participants from North America, one from South America, four from Asia, and 27 from Europe. Members included both males and females (males $=19$, ratio $=56 \%$, females $=15$, ratio $=$ $44 \%$ ). There were sixteen participants-seven males and nine females-with at least a doctorate or advanced level qualifications. 


\section{Procedure of conduct of study}

To begin the study, the researchers emailed the web link (http://www.surveyshare.com/s/AQAGIVC) of the survey to 54 globally scattered PLE experts who had earlier pledged to participate in response to this Delphi invitation. The survey link contained an introduction, purpose, and context of the study, an explanation of modified Policy Delphi technique, the commitment required from participants in terms of time and feedback, the expectation of researchers about Delphi results, and the actual questionnaire which was developed from the literature review. The specific context that the participants were asked to consider was "what it means to be a teacher at higher education level in this ever changing digital age and what do they think are the roles that a university teacher should perform while practising PLE-driven pedagogy?” In response to this email, a total of 36 PLE experts returned completed demographic survey forms. However, by the third round, this number had further reduced to 34 as two participants failed to return their responses in time during the second round of study. Therefore, the researchers did not count their responses in subsequent rounds.

The researchers served two questions to the participants through the initial questionnaire. The first question was on reviewing the titles and task descriptions of each of the 36 roles. The second question was on rating university teachers' readiness for PLE-driven pedagogy. The participants were given 10 days between two rounds to review and return the questionnaire. At the end of each round, every participant was provided with a synopsis of new and old discussion topics. The researchers kept the debate open enough to enable new perspectives to be shared freely. Many participants commented in the free form debate section. Participants' agreement with the questionnaire could be seen as an adequate representation of the debate. Throughout the process, the facilitation was low profile and restricted to the procedure only. The study lasted for three rounds until it reached an acceptable level of consensus on the majority of responses. Afterwards, the researchers aggregated the results in a concluding report.

\section{Data analysis}

At the end of the first round, analyses of responses to the questionnaire were carried out using the appropriate statistical tests. The researchers sought participants' agreement or acceptance of probed statements on 5-1 Likert scale, ranging from strongly agree to strongly disagree. This data was then used to calculate the panel mean value (M) to ascertain the central tendency of the data set, and the interquartile range (IQR) to measure participants' consensus level. Thus, to determine the level of consensus level, the IQR level of 25 to 75 percent (the current norm of IQR level) was selected. For this study, the researchers relied on three levels of consensus: high consensus (IQR $<=0.5$ ), moderate consensus $(0.5<=\mathrm{IQR}<=1.0)$, and low consensus $(1.0<=\mathrm{IQR}<=1.5)$. In general, the Delphi rounds are terminated when moderate to high convergence on consensus (IQR $<=1.0$ ) is reached on the majority of responses. Thus, the researchers stopped the Delphi probe after the third round and started analysis of the data.

The researchers purposefully moved forward to the further rounds. It was the aim to achieve either high consensus or to gain stability on probed statements. From the second round and onwards, the researchers provided the participants with a synopsis of the previous round's debate. This synopsis was specifically customized for each participant. It was supported with the panel mean value, inter-quartile range, and each individual participant's response (R) to a particular statement. With this information in hand, each participant could quickly ascertain how her previous round answer correlated with the panel mean value. It gave an opportunity for each participant to either change her previous round response with panel mean value (submit to the collective wisdom of the panel) or retain her response while providing the proper justification of this (why her answer should be valued). This information sharing was meant to encourage the panel to take informed decisions in the next round.

Table 1 shows the status of one of the free-form debate section questionnaire statements during the third round of Delphi. It is a comment which was provided during the first round by one of the Delphi participants on the instructional or learning designer role of university teachers. The table also shows the previous round's response of the participant for whom this statement was intended and the data analysis information of the statement which was performed by the researchers at the end of the second round. In Delphi studies, data analysis of questionnaire statements is performed at the end of each round to ascertain whether participants have reached the desired level of consensus or not. Such information guides the researchers to either proceed for further Delphi rounds or to stop the study at this stage and 
summarize the results. The table data shows that the participant strongly agrees with the suggestion as provided in the comment. The analysis indicates that the Delphi panel also strongly agrees that it should accept this suggestion. However, up to the second round, the comment only gains moderate consensus. Thus, in order to gain further consensus (high consensus level) for this item and for other statements as well, a new Delphi round was required. This statement and its data analysis, which was customized for each participant, were returned to Delphi participants to give them one more chance of achieving high consensus (if possible).

Table 1

A questionnaire statement at the start of the third round of Delphi

\begin{tabular}{|l|l|l|l|l|l|l|}
\hline \multicolumn{2}{|c|}{ Instructional or learning designer } & \multicolumn{3}{|c|}{ Your response? } \\
\hline & $\begin{array}{l}\text { A university teacher may involve her students in learning by } \\
\text { designing effective learning practices and collective } \\
\text { dialogues to facilitate real-life examples that lead them } \\
\text { towards innovation. }\end{array}$ & & & & & \\
$\begin{array}{l}\text { Free-form } \\
\text { debate section }\end{array}$ & $\begin{array}{l}\text { R }=5 \text { (Strongly Agree) } \\
\mathrm{M}=4.5 \text { (Strongly Agree) } \\
\text { IQR = 1.0 (Moderate Consensus) }\end{array}$ & 4 & 3 & 2 & 1 \\
\hline
\end{tabular}

Note. The following abbreviations are used: $\mathrm{R}$ = individual participant's response in previous round; $\mathrm{M}=$ panel agreement; IQR = panel consensus level

Table 2 shows the analysis of statement discussed in Table 1 above. This collective analysis shows how the values of the panel mean and inter-quartile range increased after one round of responses. The analysis shows that the statement was strongly accepted $(M>=4.5)$ after the second round. However, the participants were able to reach the highest level of consensus (IQR $<=0.5)$ only after the third round. Based on this analysis report, the researchers marked this result as satisfactory.

Table 2

Data analysis status of a questionnaire statement

\begin{tabular}{|l|l|l|l|l|}
\hline \multicolumn{2}{|c|}{ Instructional or learning designer } & \multirow{2}{*}{ Responses } & \multicolumn{2}{|c|}{ Data analysis } \\
\cline { 4 - 5 } & $\begin{array}{l}\text { A university teacher may involve her students in } \\
\text { learning by designing effective learning practices } \\
\text { and collective dialogues to facilitate real-life } \\
\text { examples that lead them towards innovation. }\end{array}$ & Second Round & 4.5 & 1.0 \\
\cline { 2 - 5 } $\begin{array}{l}\text { Free-form } \\
\text { debate section }\end{array}$ & $\begin{array}{l}\mathrm{R}=5 \text { (Strongly Agree) } \\
\mathrm{M}=4.5 \text { (Strongly Agree) } \\
\mathrm{IQR}=1.0 \text { (Moderate Consensus) }\end{array}$ & Third Round & 4.6 & 0.5 \\
\cline { 3 - 5 } & & & & \\
\hline
\end{tabular}

Note. The following abbreviations are used: $\mathrm{M}=$ panel agreement; IQR=panel consensus level

Table 3 shows the collective analysis of university teachers' readiness for PLE-driven pedagogy. The analysis shows that up to the third round, the participants were able to accept the statement with only basic agreement $(3.5<=\mathrm{M}<=4.5)$. However, it is worth noting that the statement achieved the highest consensus (IQR $<=0.5$ ) only after the second round. 
Table 3

Data analysis status of research question 2

\begin{tabular}{|l|l|l|l|}
\hline \multicolumn{1}{|c|}{ Research question 2 } & \multirow{2}{*}{ Responses } & \multicolumn{2}{|c|}{ Data analysis } \\
\cline { 3 - 5 } & & \multicolumn{1}{|c|}{ M } & \multicolumn{1}{|c|}{ IQR } \\
\hline \multirow{2}{*}{$\begin{array}{l}\text { To what extent is today's university teacher capable or ready } \\
\text { of assuming the new roles that have been suggested? }\end{array}$} & Second Round & 3.6 & 0.5 \\
\cline { 2 - 5 } & Third Round & 4.2 & 0.5 \\
\hline
\end{tabular}

Note. The following abbreviations are used: $\mathrm{M}=$ panel agreement; IQR=panel consensus level

Table 4 shows participants' comments on university teacher roles and readiness for PLE-driven pedagogy made during the three rounds of this Delphi process. It also depicts the strategy devised by the researchers to inform whether to accept or reject a comment. Appropriate weights were assigned to agreement and consensus levels to analyse table data. As with similar studies, the researchers assigned balanced weights to the agreement level from +2 to -2 . As achieving high consensus remains the main objective of any Delphi study, the biased weights from 0 to -2 were assigned to the three consensus levels. The researchers assigned zero to high consensus ( $H=0)$, minus-one to moderate consensus ( $M=-1)$, and minus-two to low consensus $(\mathrm{L}=-2)$. The objective of assigning negative weights to moderate and low consensus levels was to reflect the difference of opinion on the probed statement among Delphi participants. However, the purpose of assigning zero weight to high consensus level was to retain the actual weight of the statement. Finally, weights of the agreement and consensus levels were summed up to final status in order to generate the final results. An example is provided to demonstrate the results' calculating process. The first statement of Table 4 achieves an A (accept) for agreement level (accept $=1$ ), and an $\mathrm{H}$ (high consensus) for consensus level (high consensus $=0$ ). Summing the two weights yields an A (accept) for Final status $(1+0=1$, accept $=1)$. This suggests that the comment made by one of the Delphi participants is accepted by this study with only simple agreement.

\section{Results}

For PLE-driven pedagogy, university teacher roles were sought against five core competencies. Data analysis of Table 4 reveals that of the 69 statements that were discussed during the three-round Delphi process, this study accepts 44 , rejects 10 , and remains undecided for the other 15 statements.

Concerning the planning and design competency, 11 out of the 14 participants' comments are accepted. The roles discussed include: planner, context analyser, designer, instructional or learning designer, and programmer. The context analyser, which was proposed by one of the participants during the first round, is accepted with a simple majority. A simple agreement is reached to merge the task description of designer with instructional or learning designer. The study received high input on the free-form debate section. The opinion "I think, in this category, university teacher must be a horizon scanner" achieved the Accept status. However, the opinion "I do not find these roles as helpful" was not able to gain an adequate level of consensus and participants' agreement, thus this study strongly rejects it. The Delphi panel has been able to accept 10 comments on instruction and learning competency of university teacher. Some new roles such as complex problem solver, critical or diverse thinker, creativity catalyst, innovator, and enquirer were proposed; however, only creativity catalyst gained adequate points to be accepted. During the process, the task description of agitator converged into enquirer. The study strongly accepts a comment that the "main problem with many teachers is their emphasis on delivering of content rather than learning process of students". 
Australasian Journal of Educational Technology, 2014, 30(2).

Table 4

Final status of statements discussed during the three rounds of Delphi

\begin{tabular}{|c|c|c|c|c|}
\hline \multirow{2}{*}{$\begin{array}{l}\text { University } \\
\text { teacher roles }\end{array}$} & Statements & \multicolumn{3}{|c|}{ Results } \\
\hline & Planning and design competency & Agreement & Consensus & Final status \\
\hline \multirow[t]{2}{*}{ Planner } & $\begin{array}{l}\text { A university teacher needs to be able to reorganize planning during learning if continuous } \\
\text { assessment needs change. }\end{array}$ & A & $\mathrm{H}$ & Accept \\
\hline & She designs effective learning and communication activities. & A & $\mathrm{H}$ & Accept \\
\hline $\begin{array}{l}\text { Context } \\
\text { analyser }\end{array}$ & She needs to know the educational context and the academic area in which she works. & A & $\mathrm{H}$ & Accept \\
\hline Designer & It seems that this role can overlap the instructional or learning designer role. & SA & M & Accept \\
\hline \multirow{3}{*}{$\begin{array}{l}\text { Instructional or } \\
\text { learning } \\
\text { designer }\end{array}$} & She provides new models and approaches to her students which are related to her own culture. & A & $\mathrm{H}$ & Accept \\
\hline & $\begin{array}{l}\text { For new teachers, perhaps the focus should be on giving them instructional or learning designer } \\
\text { training rather than the traditional skills which focus on how to present learning material to the } \\
\text { students. }\end{array}$ & A & $\mathrm{H}$ & Accept \\
\hline & $\begin{array}{l}\text { University teachers may involve their students in learning by designing effective practices and } \\
\text { collective dialogue to facilitate real life examples that lead students toward innovations. }\end{array}$ & A & $\mathrm{H}$ & Accept \\
\hline \multirow[b]{2}{*}{ Programmer } & She needs to design and deliver learning environments by utilizing learning for universal design. & A & $\mathrm{H}$ & Accept \\
\hline & $\begin{array}{l}\text { It is not only the students' programming related problems which need to be solved! What about the } \\
\text { behavioural ones? How will students learn to manage their own digital identity? }\end{array}$ & A & M & Undecided \\
\hline \multirow{5}{*}{$\begin{array}{l}\text { Free-form } \\
\text { debate section }\end{array}$} & $\begin{array}{l}\text { The planning and design competency expects university teachers to involve their students in the } \\
\text { course's planning and design activities. }\end{array}$ & A & M & Undecided \\
\hline & I do not find these roles as helpful. & $\mathrm{U}$ & $\mathrm{L}$ & $\begin{array}{l}\text { Strongly } \\
\text { Reject }\end{array}$ \\
\hline & I associate programmer with programming rather than the guiding role described. & SA & M & Accept \\
\hline & I think, in this category, university teachers must be horizon scanners. & A & $\mathrm{H}$ & Accept \\
\hline & I would suggest combining designer and instructional or learning designer into just one role. & SA & $\mathrm{H}$ & $\begin{array}{l}\text { Strongly } \\
\text { Accept }\end{array}$ \\
\hline $\begin{array}{l}\text { University } \\
\text { teacher roles }\end{array}$ & Instruction and learning competency & Agreement & Consensus & Final status \\
\hline Master artist & Merge this role with alchemist and put it in the use of technology competency. & SA & M & Accept \\
\hline
\end{tabular}


Australasian Journal of Educational Technology, 2014, 30(2).

Table 4 (cont...)

Final status of statements discussed during the three rounds of Delphi

\begin{tabular}{|c|c|c|c|c|}
\hline Lecturer & $\begin{array}{l}\text { Instructor is a more suitable name for this role as teaching involves more technology use in } \\
\text { pedagogies these days. }\end{array}$ & A & $\mathrm{H}$ & Accept \\
\hline Demonstrator & Instructing and demonstrating are similar terms with little difference. I would suggest a merger. & SA & $\mathrm{H}$ & $\begin{array}{l}\text { Strongly } \\
\text { Accept }\end{array}$ \\
\hline $\begin{array}{l}\text { Complex } \\
\text { problem solver }\end{array}$ & $\begin{array}{l}\text { She needs to solve a variety of problems of different fields, such as education, science, sociology, } \\
\text { etc. }\end{array}$ & $\mathrm{U}$ & $\mathrm{L}$ & $\begin{array}{l}\text { Strongly } \\
\text { Reject }\end{array}$ \\
\hline Critical thinker & $\begin{array}{l}\text { The university teacher needs to think innovatively to provide her students with out of the box } \\
\text { solutions to problems. }\end{array}$ & $\mathrm{U}$ & $\mathrm{L}$ & $\begin{array}{l}\text { Strongly } \\
\text { Reject }\end{array}$ \\
\hline Theoriser & Delete this role. & A & M & Undecided \\
\hline Learner & I would prefer the term life-long learner rather than the term learner. & A & M & Undecided \\
\hline \multirow{2}{*}{ Critic } & For critic, I would rather prefer self-reflection as term and reflector or process mediator as role. & $\mathrm{U}$ & M & Reject \\
\hline & Please add connotation of reviewer for this role. & A & $\mathrm{H}$ & Accept \\
\hline \multirow[t]{2}{*}{ Agitator } & $\begin{array}{l}\text { Agitator keeps asking students in order to support in their learning and to guide them in their } \\
\text { research. It is not about delivering content, but to help her students to build their knowledge about } \\
\text { world artefacts. }\end{array}$ & A & $\mathrm{H}$ & Accept \\
\hline & Agitator is more than an attitude. & A & M & Undecided \\
\hline $\begin{array}{l}\text { Creativity } \\
\text { catalyst }\end{array}$ & She needs to guide the progress of creative expression in students' learning processes. & A & $\mathrm{H}$ & Accept \\
\hline Innovator & Innovator applies new and innovative approaches in her teaching. & A & M & Undecided \\
\hline Motivator & Put motivator in communication and interaction competency. & A & $\mathrm{H}$ & Accept \\
\hline \multirow{3}{*}{$\begin{array}{l}\text { Free-form } \\
\text { debate session }\end{array}$} & $\begin{array}{l}\text { I do not think many university teachers would participate in extensive preparation, but some } \\
\text { introduction to these roles would be helpful. These skills take years to develop. }\end{array}$ & A & $\mathrm{H}$ & Accept \\
\hline & Enquirer is more suitable term than agitator. & A & $\mathrm{H}$ & Accept \\
\hline & $\begin{array}{l}\text { Main problem with many university teachers is that they put more emphasis on delivery of content } \\
\text { rather than the learning process of students. }\end{array}$ & SA & $\mathrm{H}$ & $\begin{array}{l}\text { Strongly } \\
\text { Accept }\end{array}$ \\
\hline $\begin{array}{l}\text { University } \\
\text { teacher roles }\end{array}$ & Communication and interaction competency & Agreement & Consensus & Final status \\
\hline $\begin{array}{l}\text { Connector or } \\
\text { Communicator }\end{array}$ & I would put together collaborator and connector or communicator roles. & A & M & Undecided \\
\hline \multirow{3}{*}{ Convener } & $\begin{array}{l}\text { Convener takes care of rules and the background of rules about how to behave and avoid } \\
\text { misbehaving in telemetric world including general aspects. }\end{array}$ & A & M & Undecided \\
\hline & Please delete this role. & $\mathrm{U}$ & $\mathrm{M}$ & Reject \\
\hline & Name of role is not appropriate. & $\mathrm{U}$ & $\mathrm{H}$ & Undecided \\
\hline
\end{tabular}


Australasian Journal of Educational Technology, 2014, 30(2).

Table 4 (cont...)

Final status of statements discussed during the three rounds of Delphi

\begin{tabular}{|c|c|c|c|c|}
\hline \multirow{2}{*}{ Salesperson } & Salesperson adapts motivating language to convince her students for learning. & A & $\mathrm{H}$ & Accept \\
\hline & Advertiser is more suitable name than Salesperson. & A & $\mathrm{H}$ & Accept \\
\hline $\begin{array}{l}\text { Facilitator or } \\
\text { partner }\end{array}$ & Are these not different roles? & A & M & Undecided \\
\hline Collector & $\begin{array}{l}\text { University teachers need to collect and share ideas, foster values, and tag starting points for self- } \\
\text { explorative processes. }\end{array}$ & A & $\mathrm{H}$ & Accept \\
\hline Collaborator & Merge it with coordinator. Tasks of both roles are almost same, i.e. collaboration. & SA & M & Accept \\
\hline Self reflector & What is missing here is the role of focusing and enabling the self-reflection process of students! & A & M & Undecided \\
\hline \multirow{2}{*}{$\begin{array}{l}\text { Free-form } \\
\text { debate section }\end{array}$} & These roles are too broad for one person. & A & M & Undecided \\
\hline & I do not find the need of convener when there is already communicator and moderator. & SA & $\mathrm{M}$ & Accept \\
\hline $\begin{array}{c}\text { University } \\
\text { teacher roles }\end{array}$ & Management and administration competency & Agreement & Consensus & Final status \\
\hline Administrator & Please read this as administrative manager. & A & $\mathrm{H}$ & Accept \\
\hline Curator & There is no need for this role. Curator is the same as scaffolding provider. & A & $\mathrm{H}$ & Accept \\
\hline \multirow{2}{*}{ Concierge } & Bizarre term is used. There is no need for this role. & SA & M & Accept \\
\hline & University teacher needs to help her students to find outside experts and knowledgeable persons. & A & M & Undecided \\
\hline Goal setter & Delete this role, as leader does the same job. & A & $\mathrm{H}$ & Accept \\
\hline $\begin{array}{l}\begin{array}{l}\text { Leader or } \\
\text { change agent }\end{array} \\
\end{array}$ & Change agent is a different role to leader. Keep it separate. & $\mathrm{U}$ & M & Reject \\
\hline Transformer & She develops difference of opinion in not only learners' minds but also in her own mind. & $\mathrm{U}$ & M & Reject \\
\hline Integrator & She integrates her learning progress with students' learning progress. & A & $\mathrm{M}$ & Undecided \\
\hline Collector & Merge this role with the sharer and put it in the use of technology competency. & A & $\mathrm{H}$ & Accept \\
\hline Coach & The task description of coach matches that of guide. Merge them into any one. & A & $\mathrm{H}$ & Accept \\
\hline $\begin{array}{l}\text { Evaluator or } \\
\text { evaluation } \\
\text { Specialist }\end{array}$ & Names are same. Evaluator is much better. & SA & $\mathrm{H}$ & $\begin{array}{l}\text { Strongly } \\
\text { Accept }\end{array}$ \\
\hline \multirow{3}{*}{$\begin{array}{l}\text { Free-form } \\
\text { debate section }\end{array}$} & Please combine and simplify some roles. & A & $\mathrm{H}$ & Accept \\
\hline & I would put coach, guide, and concierge into the instruction and learning competency. & $\mathrm{U}$ & $\mathrm{M}$ & Reject \\
\hline & Negative connotations are used for administrative manager or bureaucrat role. & $\mathrm{U}$ & $\mathrm{M}$ & Reject \\
\hline
\end{tabular}


Australasian Journal of Educational Technology, 2014, 30(2).

Table 4 (cont...)

Final status of statements discussed during the three rounds of Delphi

\begin{tabular}{|c|c|c|c|c|}
\hline $\begin{array}{l}\text { University } \\
\text { teacher roles }\end{array}$ & Use of technology competency & Agreement & Consensus & Final status \\
\hline \multirow{2}{*}{ Alchemist } & Please find another name for this role. Alchemists did not succeed. People want change. & A & $\mathrm{H}$ & Accept \\
\hline & Merge this role with master artist. & A & $\mathrm{H}$ & Accept \\
\hline \multirow{2}{*}{$\begin{array}{l}\text { Network } \\
\text { administrator }\end{array}$} & Change name to network manager. & SA & $\mathrm{H}$ & $\begin{array}{l}\text { Strongly } \\
\text { Accept }\end{array}$ \\
\hline & There is an ambiguous overlap with other functions. Change name and description. & A & $\mathrm{H}$ & Accept \\
\hline \multirow{2}{*}{ Technician } & How can a teacher be a technician? Please change name or merge it with the technologist. & A & $\mathrm{H}$ & Accept \\
\hline & I do not agree with the phrase “make a student...” Perhaps help or guide are suitable terms. & A & $\mathrm{H}$ & Accept \\
\hline Media publisher & Media publisher does not fit. It is included in the tasks of technologist. & A & $\mathrm{H}$ & Accept \\
\hline $\begin{array}{l}\text { Digital literacy } \\
\text { expert }\end{array}$ & A university teacher needs to excel in all forms of digital literacy. & A & $\mathrm{H}$ & Accept \\
\hline Technologist & In current scenarios, the more suitable name would be the digital technology expert. & SA & M & Accept \\
\hline \multirow{2}{*}{$\begin{array}{l}\text { Techno- } \\
\text { pedagogist }\end{array}$} & $\begin{array}{l}\text { A university teacher applies appropriate tools to each learning activity and promotes variety in } \\
\text { leaning styles. }\end{array}$ & A & $\mathrm{H}$ & Accept \\
\hline & A more suitable name for this role would be the digital literacy expert. & A & $\mathrm{H}$ & Accept \\
\hline \multirow{2}{*}{$\begin{array}{l}\text { Disruptive } \\
\text { technologist }\end{array}$} & She adopts technology to improve her teaching and to let change happen in her methodology. & $\mathrm{A}$ & M & Undecided \\
\hline & Technologist would be a more suitable name for this role. & A & $\mathrm{H}$ & Accept \\
\hline $\begin{array}{l}\text { Free-form } \\
\text { debate section }\end{array}$ & Please add participator and digital citizen roles in this category. & $\mathrm{U}$ & M & Reject \\
\hline
\end{tabular}

Note. The following abbreviations are used: $\mathrm{SA}=$ Strongly Agree $=2 ; \mathrm{A}=$ Agree $=1 ; \mathrm{U}=$ Undecided = 0; $\mathrm{DA}=\mathrm{Disagree}=-1 ; \mathrm{SD}=\mathrm{Strongly}$ Disagree $=-2 ; \mathrm{H}=$

High Consensus = 0; $\mathrm{M}=$ Moderate Consensus $=-1 ; \mathrm{L}=$ Low Consensus $=-2$ 
Of 12 comments on the communication and interaction competency, only five are accepted. Salesperson as a definition of the teacher role was noted as inappropriate by one of the participants; consequently, the panel agreed to change this to advertiser. Task descriptions of convener, self-reflector and communicator were discussed; however, no consensus was developed before the end of the study; thus rejected. There are 8 comments for management and administration competency which this study accepts. One of the participants' opinions regarding changing the name of curator to scaffolding provider trended toward acceptance; however, as analysis shows, the panel instead agreed to delete this role in the end. Proposals about putting coach, guide, concierge, and goal setter into instruction and learning competency have also been rejected. The Undecided status of integrator suggests not carrying it forward as one of a university teacher's roles for PLE-driven pedagogy.

The use of technology competency also received a lot of attention by the participants. This was probably due to the huge impact of technology on teaching and learning in the digital age. Participants proposed many new roles against this competency of university teacher, such as digital literacy expert, digital technology expert, techno-pedagogist, disruptive technologist, participator, digital citizen, and content validator. However, as analysis shows, this study accepts only the digital literacy expert. The panel agreed and achieved consensus to change the name of technologist to digital technology expert. Task descriptions of technician, disruptive technologist and technologist were merged together to be included into the task description of digital technology expert, and of alchemist into the master artist.

Finally, as the data analysis advises, this study settles on 28 roles on which the Delphi panel was able to reach a consensus and agreement. Therefore, based on the insights gained through this expert advice, the researchers revised the task descriptions of each of these 28 roles, which are shown in Table 5.

Table 5

Task descriptions of 28 PLE-driven pedagogy roles of a university teacher

\begin{tabular}{|l|l|}
\hline \multicolumn{1}{|c|}{ Competency } & \multicolumn{1}{c|}{ University teacher roles } \\
\hline Planning \\
and & 1. Planner: Tasks include: \\
- To introduce students to PLE and personalized learning concepts. \\
- To support students to build their PLE. \\
- To link students' formal and informal learning to envision a meaningful PLE. \\
2. Context Analyser: Tasks include: \\
- To use teaching and learning tools according to purpose, need, and context of \\
learning. \\
- To analyse the internal and external factors of a learning environment. Internal \\
factors include the understanding of students' preferences, course demand, type, and \\
level of support required, etc. External factors include the understanding of \\
technology access, network of resources, and outside learning opportunities which \\
can be made available to students. \\
- To adjust support accordingly in order to fit demands of internal and external factors. \\
3. Instructional or Learning Designer: Tasks include: \\
- To offer students the consistency of design and functionality across various tools to \\
support their learning processes. \\
- To use learning designs which help create automatic personalized learning activities. \\
- To involve students in collaborative and networked learning practices and collective \\
dialogue. \\
- To familiarize students with new models and approaches of learning related to their \\
own culture. \\
- To enhance students' learning experiences by adding examples of real life events. \\
4. Programmer: Tasks include: \\
- To collect and manage learning artefacts for students. \\
- To help students in solving their programming related problems, such as, managing \\
- Tocial networks, setting wikis, blogs, etc. \\
in a course, technology acceptance and frustration issues, etc.
\end{tabular}


Table 5 (cont ...)

Task descriptions of 28 PLE-driven pedagogy roles of a university teacher

\begin{tabular}{|c|c|}
\hline & 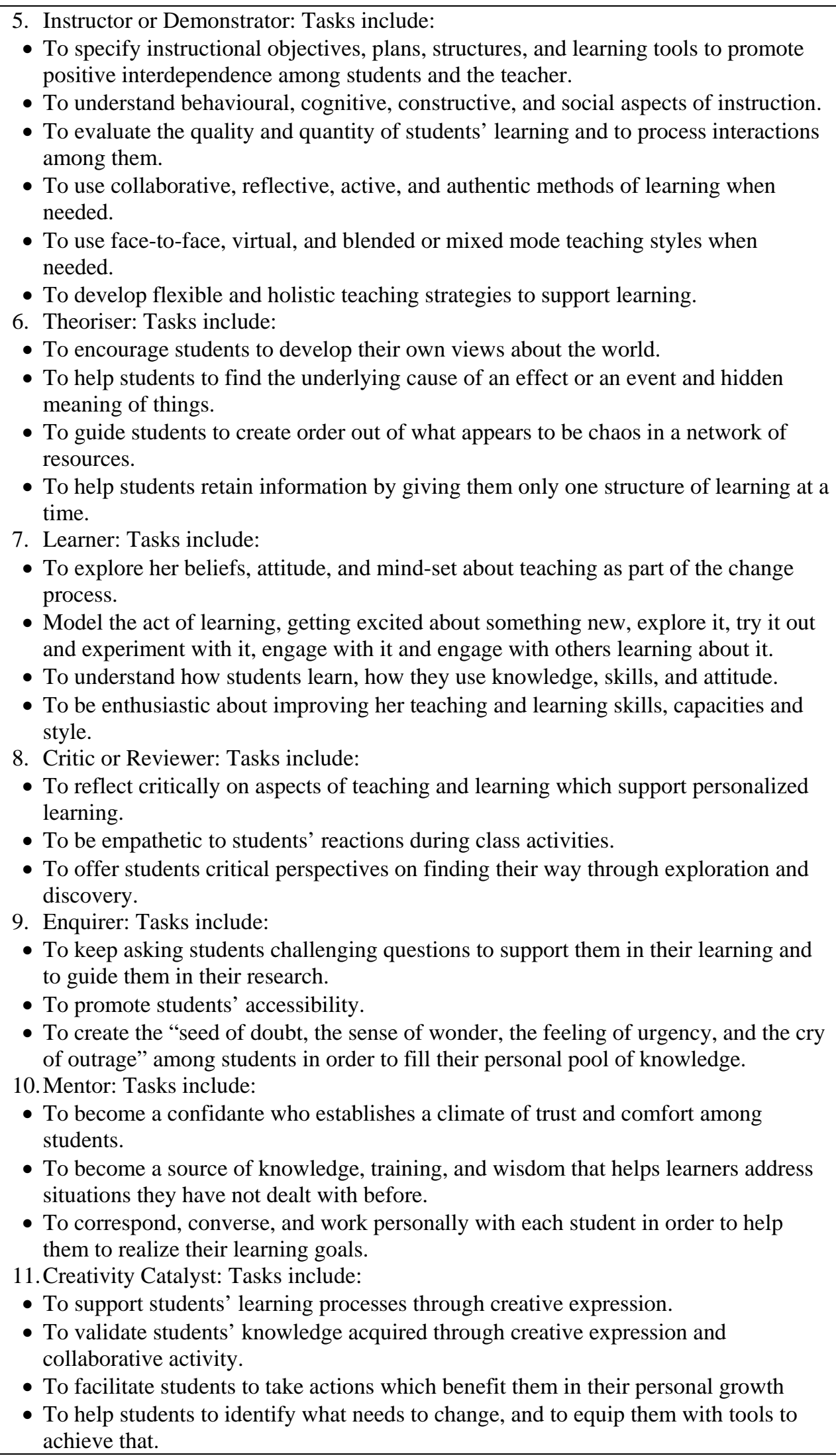 \\
\hline
\end{tabular}


Table 5 (cont ...)

Task descriptions of 28 PLE-driven pedagogy roles of a university teacher

\begin{tabular}{|c|c|}
\hline & $\begin{array}{l}\text { 12. Innovator: Tasks include: } \\
\text { - To use new, improved, and innovative teaching and learning approaches. } \\
\text { - To use learning equipment, models, simulations, and movies in order to identify the } \\
\text { learning preferences of students. } \\
\text { - To update herself with better learning strategies, techniques, and resources when } \\
\text { available. } \\
\text { To encourage students to seek their own answers to unanswered questions. }\end{array}$ \\
\hline $\begin{array}{l}\text { Communication } \\
\text { and } \\
\text { interaction }\end{array}$ & $\begin{array}{l}\text { 13. Coordinator or Collaborator: Tasks include: } \\
\text { - To put a high value on collegiality and coordination among students. } \\
\text { - To encourage and initiate collaborative learning activities among students. } \\
\text { - To monitor students' behaviour in order to make sure that they are connected and } \\
\text { - working collaboratively. } \\
\text { - To develop a suitable learning framework by which learners can easily collaborate, } \\
\text { connect, and integrate. } \\
\text { - To solicit input from all sectors of the educational community including the parents } \\
\text { while planning, managing, implementing, and evaluating the course program. } \\
\text { 14. Facilitator or Partner: Tasks include: } \\
\text { - To facilitate students to adapt to the learning environment. } \\
\text { - To encourage and manage interactions between learning resources and students. } \\
\text { - To manage learning content before it becomes complex. } \\
\text { 15. Connector or Communicator: Tasks include: } \\
\text { - To link with students either by online or by offline means in order to be located } \\
\text { - when needed. } \\
\text { - To link isolated resources and communities of learning with each other. } \\
\text { - To draw associations among learners, learning artefacts, and learning theories and } \\
\text { models in order to infer latent factors and relationships among them. } \\
\text { 16. Moderator: Tasks include: } \\
\text { - To initiate, manage, control, and maintain interactive discussion and dialogue with } \\
\text { students. } \\
\text { - To include critical course concepts for discussion and dialogue with students. } \\
\text { - To identify areas of consensus among students. } \\
\text { 17. Advertiser: Tasks include: } \\
\text { - To adapt motivating language in order to promote a set of values with students. } \\
\text { - To identify opportunities and strategies for improving students' performance. } \\
\text { - To encourage students to have self-belief. } \\
\text { 18. Participant: Tasks include: } \\
\text { - To encourage students in peer learning and participation. } \\
\text { - To ensure participation of all stakeholders of students' learning process. } \\
\text { - To understand, encourage, acknowledge, and reinforce students' contributions. } \\
\text { 19. Motivator: Tasks include: } \\
\text { - To motivate students to take collaborative action and make social links. } \\
\text { - To motivate students to do things which they believe they cannot do on their own. } \\
\text { - To motivate students to take ownership of and to control their own learning } \\
\text { processes. }\end{array}$ \\
\hline
\end{tabular}


Table 5 (cont ...)

Task descriptions of 28 PLE-driven pedagogy roles of a university teacher

\begin{tabular}{|c|c|}
\hline $\begin{array}{l}\text { Management } \\
\text { and } \\
\text { administration }\end{array}$ & $\begin{array}{l}\text { 20. Leader or Change Agent: Tasks include: } \\
\text { - To become an effective leader who can inspire students through her personality and } \\
\text { power. } \\
\text { - To understand the current and future learning climate of students and to formulate } \\
\text { strategies that respond to that climate. } \\
\text { - To increase the knowledge capacity of students with a belief that someday this } \\
\text { knowledge will surpass her own. } \\
\text { 21. Administrative Manager: Tasks include: } \\
\text { - To decide what combination of instructional methods, presentation modes, and } \\
\text { distribution techniques will best deliver the final program to the learners. } \\
\text { - To develop and adapt planned actions such as how to respond to students' } \\
\text { expectations, learning needs, etc. } \\
\text { - To administer the classroom according to the spaces and channels of communication. } \\
\text { 22. Guide or Coach: Tasks include: } \\
\text { - To empower students to enjoy their successes and to own their mistakes. } \\
\text { - To support students to become self-reliant and improve on their skills, taking } \\
\text { responsibility for their own learning. } \\
\text { - To provide students with constructive comments on assignments, quizzes, and other } \\
\text { activities. } \\
\text { 23. Evaluator: Tasks include: } \\
\text { - To provide students with filtered information about relevant learning resources based } \\
\text { on her prior experience. } \\
\text { - To perform front-end analysis in order to compare actual and ideal performance } \\
\text { levels of students. } \\
\text { - To conduct a needs assessment of learning resources which are required in learning } \\
\text { activities } \\
\text { - To measure students' success by appropriate learning interventions. } \\
\text { - To assess the efficacy of learning processes, learning services, and programmes } \\
\text { offered to students. }\end{array}$ \\
\hline $\begin{array}{l}\text { Use } \\
\text { of } \\
\text { technology }\end{array}$ & $\begin{array}{l}\text { 24. Master Artist: Tasks include: } \\
\text { - To convert ordinary and dull things into something innovative and surprising. } \\
\text { - To analyse rhythm in dissimilar things to bring them together and to bring them out. } \\
\text { - To determine when, how, and where appropriate learning tools or technologies could } \\
\text { be used. } \\
\text { 25. Sharer or Collector: Tasks include: } \\
\text { - To share cultures, ideas, resources, materials, mailing lists, links, online file areas, } \\
\text { etc with students. } \\
\text { - To share or reveal learning content and conversation structure to students only when } \\
\text { it is needed. } \\
\text { - To share e-portfolios, online identities, and learning environments with students. } \\
\text { 26. Network Manager: Tasks include: } \\
\text { - To support students to master skills required to construct a network of information } \\
\text { that works within a flexible structure. } \\
\text { - To enhance this network of information by drawing students' attention to potential } \\
\text { content. } \\
\text { - To evaluate students' effectiveness in using the network of information and to } \\
\text { monitor students’ progress to make sure they are working efficiently. } \\
\text { - To support applications of learning, learning communities, and groups of learners. } \\
\text { - }\end{array}$ \\
\hline
\end{tabular}


Table 5 (cont ...)

Task descriptions of 28 PLE-driven pedagogy roles of a university teacher

\begin{tabular}{|l|l|}
\hline 27. Digital Technology Expert: Tasks include: \\
- To provide the students with technical knowledge of integrating various Web 2.0 \\
resources and services. \\
- To train students on how to tackle common technological issues. \\
- To support students to adapt to the changes brought on by new learning technologies. \\
28. To know how to use learning platform tools for tutoring, authoring, and annotation \\
purposes. Digital Literacy Expert: Tasks include: \\
- To excel in various aspects of digital literacy, such as creating a presentation in \\
PowerPoint, creating and posting course content on a website, podcasting a video, \\
etc. \\
- To use software applications and web-based resources attractively and efficiently. \\
To validate data before putting it into a model.
\end{tabular}

\section{Limitations of the Delphi method}

Like other qualitative research methods, the Delphi technique is not without weaknesses. The limitations inherent in the method itself include the biases introduced by the moderators while selecting the respondents, designing the questionnaire, processing the results, and the integrity of generated information, which is fundamentally based on participants' personal values and experiences (Na, 2006). In addition to these general limitations, some problematic situations may occur at the start of the study when researchers inappropriately push to include unimportant questions by over-estimating their significance to the study. This situation can either invalidate the study or can create significant hardships for participants (O’Neill et al., 2011). A worse situation could even occur if the researchers ask the correct questions, but the participants cannot understand the question statements correctly. Franklin and Hart (2006) note that "the validity and reliability of a Delphi study rests in the selection of the panel, the creation of the instruments for collecting responses, the care with which the researchers used the responses of the panellists to improve upon the instruments as suggested by the panellists, and the interpretation of the data" (p. 220). Shaikh and Khoja (2011) claim that the role of the researchers is very critical to the reliability of the Delphi study as they control the key elements of implementation that could directly affect the outcomes. However, the researchers can still overcome the weaknesses intrinsic into the process by modifying the procedure of conducting the Delphi study to fulfil their needs.

For this modified Policy Delphi study, the researchers designed a protocol that was sensitive to frequently discussed issues as stated above. Each phase of this study included opportunities for open and free debate to prompt non-restrictive discussion and to allow reflections on the conduct of the study. As indicated in the methodology section, the researchers used www.surveyshare.com, a web survey and questionnaire tool, to protect the privacy of Delphi participants. Only the researchers knew their identity. To ensure selection of a representative sample of teachers with an interest in PLE-driven pedagogy, a strict protocol that covered length of domain and teaching experience, popularity within academia or industry, multiplicity of expertise, record of accomplishments, willingness to participate, recommended by others, etc. was devised and implemented. The only criticism that remains valid as a limitation of this study is the use of the initial key questionnaire by the researchers, and inadvertently influencing participants' responses or the direction of thought. As noted in the methodology section, the initial questionnaire was carefully developed from the existing literature. In addition, participants had, and took, the opportunity to add new questions to the questionnaire or to modify the existing ones. They were also allowed to initiate any new thread of discussion in the free-form debate section.

\section{Conclusions}

The higher education sector at a global level is under constant pressure to respond to the effectiveness of PLE-driven pedagogy that is a learner-centred, collaboratively constructed, active, and inquiry-oriented process (Schneckenberg, Ehlers, \& Adelsberger, 2011; McLoughlin \& Lee, 2010). The PLE-driven pedagogy allows the university teacher to engage her students in constructive, emotional, cultural, and 
deeply intrapersonal learning experiences (Leadbeater, 2010). This study highlighted the importance of PLE-driven pedagogy within the context of higher education. It aimed at identifying changes required in the traditional roles and competencies of the university teacher in the context of prevailing developments accomplished by the free and easy availability of social software and Web 2.0 tools. Therefore, university teacher roles for PLE-driven pedagogy were investigated. An online modified Policy Delphi technique was used to answer the following two questions: (a) the introduction of the concept of PLE to teaching and learning in higher education has led to a change in students' learning processes, learning styles, and pedagogies to be more learner-centred. What changes are required to the traditional roles and related competencies of the university teacher to cater for this new situation, and (b) to what extent is today's university teacher capable or ready of assuming the new roles that have been suggested? The 28 roles were determined (see Table 5) as a result of consensus from a panel of 34 expert teachers drawn from the globally scattered PLE community. Three Delphi rounds were required before either reaching consensus or stability in group responses. Upon completion of the Delphi data analysis, conclusions have been drawn to answer the two research questions.

\section{Research question 1}

The first research question was examined through data collected from the initial questionnaire and Table 4. Table 5 summarises the 28 roles of the university teacher for PLE-driven pedagogy, which have been developed from the accepted statements of Table 4 and from the task descriptions which appeared in the initial questionnaire.

Results indicate that PLE-driven pedagogy supports learner-centredness and fosters students' selfregulated learning skills. The existing learning designs and practices do not cater to 21st century teaching and learning demands. It is also obvious from Delphi participants' comments, such as "A teacher should provide new models and approaches to her students which are related to her own culture" and "A university teacher needs to be able to reorganize planning during learning process if continuous assessment requires change". This finding supports the literature that suggests extra tasks for the instructional or learning designer and planner (Downes, 2011; Minocha et al., 2011). This finding implies that today's university teacher needs to update her current competencies to cater to the demands of PLE-driven pedagogy.

It is evident from this Delphi debate that existing learning designs and practices need to be updated for the automatic creation of personalized learning activities. The other roles that are consistent with existing literature (see Shaikh \& Khoja, 2012; Kitsantas \& Dabbagh, 2011; Minocha et al., 2011; Downes, 2011; Siemens, 2010) and are accepted by this study include creativity catalyst, learner, critic, enquirer, innovator, participant, collector, coach, and digital technology expert. The collector, coach, and creativity catalyst are consistent with Downes' (2011) judgement, who used the words bureaucrat, counsellor, and promoter of learner autonomy for these roles, and with Siemens' (2010) thought, who used the words aggregator, amplifier, and way finder for these roles. Delphi participants' viewpoints about collector, critic, and innovator mirror the importance of these roles of the university teacher for PLE-driven pedagogy. They view collector as "a person who shares ideas, fosters shared values and enables starting points for self-explorative process", critic as "a person who keeps asking students to guide their learning and to help them research and achieve conclusions", and innovator as "a person who applies new and innovative approaches in her teaching”. These findings imply that a university teacher needs to support her students in their first use of technology in learning, enrich her instruction with new and innovative practices, and to be adept in communication, management, and technological competencies.

University teacher roles for technology-enhanced learning either for face- to-face or online learning modes would continue to be indispensable for PLE-driven teaching practices. In this regard, a university teacher's roles for technology-enhanced learning accepted by this study include instructor, theoriser, mentor, facilitator, collaborator, moderator, communicator, motivator, leader, evaluator, and administrative manager. This finding implies that empowering students to become self-reliant, focused, and smart learners, who can progress through creative expression and self-growth, enjoy their achievements and learn from their mistakes, and own responsibility for their learning, is included in the tasks of the university teacher who is PLE-aware. 
Consistent with the literature, participants also single out university teacher roles which are necessary to accomplish PLE-driven pedagogy. These include context analyser, who chooses appropriate learning tools and pedagogy according to the context of learners, learning objectives, and learning environment; master artist, who transforms normal students into smart learners, and alters ordinary objects that may be useful in learning into something innovative and surprising master pieces; network manager, who helps students in mastering networked learning skills and acquiring for them resources and information that would work within a fluid network structure; and digital literacy expert, who by utilizing common software applications and web-based resources elegantly and efficiently excels in various aspects of digital literacy, such as creating a presentation in PowerPoint, creating and posting course content on a website, podcasting a video, and so on. This finding implies that the university teacher needs to produce technology savvy and smart students who are not only skilled in the world of technology, but who can also cope with the adverse effects of technology.

It is apparent from the majority of opinions provided by the Delphi participants that, besides realizing the importance of these roles, they were also worried about how a single person alone can perform so many roles. This uncertainty was noticeable in participants' comments, such as "I do not find these names as helpful", "these roles are too broad for one person", and "please combine and simplify some roles." However, the comment "I do not think many university teachers would participate in extensive preparation of these roles, but some introduction to these roles would be helpful. The skills take years to develop" resolved their concerns to some extent. Moreover, it is clear from the results which suggest different titles for roles than appeared in the reviewed literature (such as a title of collector for aggregator and bureaucrat, and a title of creativity catalyst for amplifier and way finder) that the task descriptions of these roles are identical. This finding implies that an insightful review by an individual can result in a little fewer or more roles with contrasting titles and task descriptions than the ones suggested by this study. In addition, it is safe to say that not every university teacher wants to perform every role nor can every university teacher perform every role. However, a good understanding of these roles is necessary for a university teacher who is PLE-aware.

\section{Research question 2}

The second research question was examined through data collected from Table 6. Results indicate that the university teacher today is very much capable of and ready to perform these new roles as discussed above. A university teacher is not only one of the more erudite members of any society, but she also has a tendency to keep herself informed and updated about any internal or external changes in her profession or in the society at large. This finding implies that a university teacher's introduction to and training for PLE-driven pedagogy is not a matter of chance, choice, opportunity, or progression; it is a matter of 21st century teaching and learning which demands learners' personalisation, learner-centredness, and selfregulated learning practices.

Table 6

Final status of research question 2

\begin{tabular}{|l|l|l|l|}
\hline \multicolumn{2}{|c|}{ Research question 2 } & \multicolumn{3}{c|}{ Results } \\
\cline { 2 - 4 } & Agreement & Consensus & Final status \\
\hline $\begin{array}{l}\text { To what extent is today's university teacher capable or ready } \\
\text { of assuming the new roles that have been suggested? }\end{array}$ & SA & H & $\begin{array}{l}\text { Strongly } \\
\text { Accept }\end{array}$ \\
\hline
\end{tabular}

Note. The following abbreviations are used: $\mathrm{SA}=$ Strongly Agree $=2 ; \mathrm{A}=$ Agree $=1 ; \mathrm{U}=$ Undecided $=$ 0 ; $\mathrm{DA}=$ Disagree $=-1 ; \mathrm{SD}=$ Strongly Disagree $=-2 ; \mathrm{H}=$ High Consensus $=0 ; \mathrm{M}=$ Moderate Consensus $=-1 ; \mathrm{L}=$ Low Consensus $=-2$

This study settled on 28 university teacher roles for PLE-driven pedagogy. It can be implied from the findings of this study that the debate around university teacher roles for PLE-driven pedagogy is ongoing and this roles list is not exhaustive. However, it is reasonable to assume that the 34 participants who belonged to the teaching and research areas of the PLE community served as a random sample of the field. Their stance is equally valuable to teachers, researchers, managers, and policy makers interested in 
PLE-driven pedagogy. Thus, it is imperative that management at a higher education level should heed the perceptions of these individuals. University teachers today need to be trained in these new roles that could be required of them in the future.

The researchers claim that the results of this study responded to the concerns about the effectiveness and outcomes of teaching and learning in the digital era. The study results also suggest that the university teacher today is very much capable of and ready to perform these new roles.

\section{Implications of the findings for future practice and policy}

A clear implication of this study is that the university teacher needs to support her students in their first uses of technology for learning. In fact, a university teacher should decide which learning resources are useful for her students to achieve a particular learning objective. The PLE supports self-regulated learning and learner-centred pedagogy. Therefore, students should be provided with proper PLE experience to benefit their learning processes. Moreover, as PLE is personal, students shall control it and adjust it accordingly. Nevertheless, students always need instructional support to decide on suitable learning artefacts.

A second implication based on the conclusions is that the university teacher ought to update her traditional pedagogical practices with new and improved PLE-driven instructional principles to cater to the demands of 21st century teaching and learning. She needs to involve herself with proposed skills and focus on contextual use of technologies in her teaching to become entrenched in these learner-centred technologies. University teachers who have earned a good reputation in PLE-driven pedagogies may be offered training sessions, workshops, and seminars for their associates. University teachers who carry out the suggested roles as identified by this study may be provided with compensation for extra time spent on curriculum development as an acknowledgement of their efforts.

A third implication stemming from the conclusions is that the university teacher needs to be adept in PLE-oriented planning, instructional, communicational, managerial, and technological competencies. This would help her to implement PLE-driven pedagogical principles in the classroom, design course material which corresponds to PLE design principles, and let her be involved in current PLE research. To achieve this, teacher trainers need to coach university teachers for one PLE competency at a time or as per the demands of the course, and then move on to other competencies once the current task is completed.

A fourth implication is that the importance of a particular role varies according to the situation. Depending on the circumstances, a university teacher may need to perform some roles more than the others. The necessity of each role depends on the educational approach used - in the traditional teachercentric system different competencies are required from those in the PLE-driven learning situation. Thus, it would probably be difficult to find a university teacher performing all the roles at one time. Therefore, good understanding of each role is essential.

Finally, as a university teacher's introduction to and training in PLE-driven pedagogy is a matter of learners' personalisation, learner-centredness, and self-regulated learning, the university teacher's development on PLE-driven pedagogical grounds should inform administrators' practice and design of a curriculum that would comply effectively with 21st century teaching and learning demands. Therefore, questions that measure the effectiveness of university teachers' PLE-driven pedagogical practices may be included in teacher evaluation forms. University teacher's personalized learning practices need to be acknowledged by the management and her extra efforts in this regard should be rewarded with honorariums, promotions, praises, etc.

\section{Recommendations for further research}

The existing educational technology literature is silent on the effectiveness and efficiency of university teacher roles as suggested by this study. No single study was found that measures university teachers' PLE-driven pedagogic roles in real classroom-based environments. Due to this situation, the researchers picked out only those roles which have been repeatedly discussed in the literature. 
Learning environments shape teachers' approaches to teaching. Practising these roles in today's technology-enhanced learning environments would inform the university teacher how PLE-driven pedagogy can be used at its best. Therefore, in order to evaluate the effectiveness of roles as suggested by this study, it is recommended that this roles list be included in pre-service and in-service university teacher training modules by means of full length courses, training workshops, seminars, etc.

The platform for selecting participants for this Delphi study was representative of the PLE field only, with mandatory expertise and interest in PLE-driven pedagogy. Thus, it is recommended that another qualitative research study be commissioned which invites experts from teaching standards development organizations at higher education levels to validate and improve the results of this study. Such organizations may include the Council for Higher Education Accreditation (CHEA), Teacher Education Accreditation Council (TEAC), Association of Teacher Educators (ATE), Association for Teacher Education in Europe (ATEE), etc.

To encourage university teachers to participate in developing their PLE-driven pedagogy skills and associated roles as suggested by this study, it is recommended that the specialized training sessions need to be arranged for university teachers that allow them to learn in an environment (e.g. a classroom-based PLE) similar to that they would provide for their students to learn in. A mechanism which monitors issues faced by university teachers at the course design, delivery, implementation, and evaluation level needs to be in place which generates reports informing university teachers about the effects of their efforts on students' learning processes.

The Delphi method is a research-based collaborative problem solving technique. It has been used as a means of generating ideas for any new or vague phenomena or as a forum for establishing facts about any present or future problem (Hasson, et al., 2000; Clayton, 1997). The researchers used this technique because the phenomenon of university teacher roles for PLE-driven pedagogy is still new and vague. This requires community contribution for establishing facts to take better decisions for future actions. Therefore, it is recommended that educational technology researchers employ this technique in their efforts to plan better learning environments for the present and future, and to further the use of the Delphi method to find solutions to ill-defined problems.

\section{Acknowledgements}

The researchers would like to extend gratitude to the participants of this Delphi research who made this project possible.

\section{References}

Archee, R. (2012). Reflections on personal learning environments: theory and practice. Procedia: Social and Behavioral Sciences, 55, 419-428. Retrieved from

http://www.sciencedirect.com/science/article/pii/S1877042812039821

Attwell, G. (2007). Personal Learning Environments - the future of eLearning? eLearingPapers, 2(1), 1-8. Retrieved from http://www.openeducationeuropa.eu/en/article/Personal-Learning-Environments---thefuture-of-eLearning\%3F

Biddle, B. J. (1986). Recent development in role theory. Annual review of sociology, 67-92.

Brill, J. M., Bishop, M. J., \& Walker, A. E. (2006). The competencies and characteristics required of an effective project manager: A web-based Delphi study. Educational Technology Research and Development, 54(2), 115-140. doi:10.1007/s11423-006-8251-y

Clark, W., Logan, K., Luckin, R., Mee, A., \& Oliver, M. (2009). Beyond Web 2.0: mapping the technology landscapes of young learners. Journal of Computer Assisted Learning, 25(1), 56-69. doi: 10.1111/j.1365-2729.2008.00305.x 
Clayton, M. J. (1997). Delphi: a technique to harness expert opinion for critical decision-making tasks in education. Educational Psychology, 17(4), 373-386. doi:10.1080/0144341970170401

Dabbagh, N., \& Kitsantas, A. (2012). Personal Learning Environments, social media, and self-regulated learning: A natural formula for connecting formal and informal learning. The Internet and higher education, 15(1), 3-8. doi:10.1016/j.iheduc.2011.06.002

Dabbagh, N., \& Reo, R. (2011). Impact of Web 2.0 on higher education. In D. W. Surry, T. Stefurak, \& R. Gray (Eds.), Technology integration in higher education: Social and organizational aspects (pp. 174-187). Hershey, PA: IGI Global. doi: 10.4018/978-1-60960-147-8.ch013

Downes, S. (2007). What connectivism is. Half an Hour. Retrieved January 25, 2012, from http://halfanhour.blogspot.com/2007/02/what-connectivism-is.html

Downes, S. (2011, March 23). The Role of the Educator. Huffington Post. Retrieved January 25, 2012, from http://www.huffingtonpost.com/stephen-downes/the-role-of-the-educator_b_790937.html

Drexler, W. (2010). The networked student model for construction of personal learning environments: balancing teacher control and student autonomy. Australasian Journal of Educational Technology, 26(3), 369-385. Retrieved from http://www.ascilite.org.au/ajet/ajet26/drexler.html

EDUCAUSE Learning Initiative (2007). Seven things you should know about Personal Learning Environments. Retrieved January 15, 2012, from http://net.educause.edu/ir/library/pdf/ELI7049.pdf

Franklin, K. K., \& Hart, J. K. (2006). Influence of web-based distance education on the academic department chair role. Educational Technology \& Society, 9(1), 213-228. Retrieved from http://www.ebiblioteka.lt/resursai/Uzsienio\%20leidiniai/IEEE/English/2006/Volume\%209/Issue\%201 /Jets_v9i1_18.pdf

Guasch, T., Alvarez, I., \& Espasa, A. (2010). University teacher competencies in a virtual teaching/learning environment: Analysis of a teacher training experience. Teaching and Teacher Education, 26(2), 199-206. Retrieved from http://dx.doi.org/10.1016/j.tate.2009.02.018

Häkkinen, P., \& Hämäläinen, R. (2012). Shared and personal learning spaces: Challenges for pedagogical design. The Internet and Higher Education, 15(4), 231-236. Retrieved from http://dx.doi.org/10.1016/j.iheduc.2011.09.001

Hargreaves, A., \& Shirley, D. (2009). The Fourth Way: The Inspiring Future for Educational Change. Corwin Press, Thousand Oaks, CA

Harrison, D. (2011). Can blogging make a difference? Campus Technology. Retrieved January 25, 2012 from http://campustechnology.com/articles/2011/01/12/can-blogging-make-a-difference.aspx

Hasson, F., Keeney, S., \& McKenna, H. (2000). Research guidelines for the Delphi survey technique. Journal of Advanced Nursing, 32(4), 1008-1015. doi: 10.1046/j.1365-2648.2000.t01-1-01567.x

Hazari, S., North, A., \& Moreland, D. (2009). Investigating pedagogical value of wiki technology. Journal of Information Systems Education, 20(2), 187-198. Retrieved from http://jise.org/Volume20/20-2/Contents-20-2.html

Hemmi, A., Bayne, S., \& Land, R. (2009). The appropriation and repurposing of social technologies in higher education. Journal of Computer Assisted Learning, 25(1), 19-30. doi: 10.1111/j.13652729.2008.00306.x

Hsu, C. C., \& Sandford, B. A. (2007). The Delphi technique: Making sense of consensus. Practical Assessment, Research \& Evaluation, 12(10), 1-8. Retrieved from http://www.srnr.arizona.edu/rnr/rnr419/publications/dephimethod.pdf 
Johnson, L., Adams, S., \& Haywood, K. (2011). The NMC horizon report: 2011 K-12 edition. Austin, Texas: The New Media Consortium. Retrieved from http://www.nmc.org/pdf/2011-Horizon-ReportK12.pdf

Kitsantas, A., \& Dabbagh, N. (2010). Learning to learn with Integrative Learning Technologies (ILT): A practical guide for academic success. Greenwich, CT: Information Age Publishing.

Leadbeater, C. (2010). We-Think: Mass innovation, not mass production. Profile Books. Retrieved from http://www.wethinkthebook.net/home.aspx

McGee, C., \& Fraser, D. (2011). The Professional Practice of Teaching. Cengage Learning. Retrieved from http://www.cengagebrain.co.nz/content/9780170223553.pdf

McLoughlin, C., \& Lee, M. J. W. (2010). Personalised and self-regulated learning in the Web 2.0 era: international exemplars of innovative pedagogy using social software. Australasian Journal of Educational Technology, 26(1), 28-43. Retrieved from http://ascilite.org.au/ajet/ajet26/mcloughlin.html

McRae, P. (2010, October 1). The Politics of Personalization in the 21st Century. ATA Magazine, 91(2). Retrieved January 25, 2012 from http://www.teachers.ab.ca/Publications/ATA\%20Magazine/Volume91/Number-1/Pages/The-Politics-of-Personalization-in-the-21st-Century.aspx

Miliband, D. (2006). Choice and voice in personalised learning. In Schooling for Tomorrow: Personalising Education. Retrieved March 27, 2012, from http://www.oecd.org/site/schoolingfortomorrowknowledgebase/themes/demand/41175554.pdf

Minocha, S., Schroeder, A., \& Schneider, C. (2011). Role of the educator in social software initiatives in further and higher education: A conceptualisation and research agenda. British Journal of Educational Technology, 42(6), 889-903. doi:10.1111/j.1467-8535.2010.01131.x

Na, S. (2006). A Delphi study to identify teaching competencies of teacher education faculty in 2015 (Doctoral dissertation, Virginia Polytechnic). Retrieved from http://wvuscholar.wvu.edu:8881//exlibris/dtl/d3_1/apache_media/L2V4bGlicmlzL2R0bC9kM18xL2F wYWNoZV9tZWRpYS8yMTAwOA==.pdf

O’Neill, S., Scott, M., \& Conboy, K. (2011). A Delphi study on collaborative learning in distance education: The faculty perspective. British Journal of Educational Technology, 42(6), 939-949. doi:10.1111/j.1467-8535.2010.01132.x

Pollard, C., \& Pollard, R. (2005). Research priorities in educational technology: A Delphi study. Journal of Research on Technology in Education, 37(2), 145-160. Retrieved from http://www.edtechpolicy.org/ArchivedWebsites/JCTE/session13_delpistudy.pdf

Schneckenberg, D., Ehlers, U., \& Adelsberger, H. (2011). Web 2.0 and competence-oriented design of learning-Potentials and implications for higher education. British Journal of Educational Technology, 42(5), 747-762. doi:10.1111/j.1467-8535.2010.01092.x

Shaikh, Z. A., \& Khoja, S. A. (2011). Role of ICT in shaping the future of Pakistani higher education system. Turkish Online Journal of Educational Technology - TOJET, 10(1), 149-161. Retrieved from http://www.tojet.net/articles/v10i1/10116.pdf

Shaikh, Z. A., \& Khoja, S. A. (2012). Role of teacher in personal learning environments. Digital Education Review, 21, 23-32. Retrieved from http:/greav.ub.edu/der/index.php/der/article/view/189/382

Sharma, R. C., \& Kawachi, P. (2012). Engaging learners in the digital age through self-discovery learning. In S. Hai-Jew (Ed.), Constructing self-discovery learning spaces online: scaffolding and decision making technologies (pp. 218-229). Hershey, PA: Information Science Reference. doi:10.4018/978-1-61350-320-1.ch012 
Sharma, R. C. (2012, October 16). Virtual Open Schooling. Keynote speech delivered at the National Consultative Workshop on Virtual Open Schooling in India in New Delhi organised jointly by National Institute of Open Schooling (NIOS), Noida and Commonwealth Educational Media Centre for Asia (CEMCA), New Delhi. Retrieved January 15, 2013 from http://www.slideshare.net/CEMCA/virtual-open-schooling

Siemens, G. (2010). Teaching in social and technological networks. Connectivism: Networked and Social Learning. Retrieved January 15, 2012 from http://www.connectivism.ca/?p=220

Smith, S. D., \& Caruso, J. B. (2010). The ECAR study of undergraduate students and information technology, 2010 (Research Study, Vol. 6). Boulder, CO: EDUCAUSE Center for Applied Research, 2010. Retrieved from http://anitacrawley.net/Resources/Reports/ECAR\%20study\%20highlights.pdf

Snelson, C., Rice, K., \& Wyzard, C. (2012). Research priorities for YouTube and video-sharing technologies: A Delphi study. British Journal of Educational Technology, 43(1), 119-129. doi:10.1111/j.1467-8535.2010.01168.x

Steele, J. L., Hamilton, L. S., \& Stecher, B. M. (2010). Incorporating student performance measures into teacher evaluation systems. technical report. RAND Corporation. Retrieved from http://www.rand.org/content/dam/rand/pubs/technical_reports/2010/RAND_TR917.pdf

Turker, M. A., \& Zingel, S. (2008). Formative interfaces for scaffolding self-regulated learning in PLEs. eLearning Papers, 14. Retrieved from http://www.openeducationeuropa.eu/en/article/FormativeInterfaces-for-Scaffolding-Self-Regulated-Learning-in-PLEs

Väljataga, T., Pata, K., \& Tammets, K. (2011). Considering students’ perspective on personal and distributed learning environments. In M. J. W. Lee, \& C. McLoughlin (Eds.), Web 2.0-based eLearning: Applying social informatics for tertiary teaching (pp. 85-107). Hershey, PA: IGI Global. doi: 10.4018/978-1-60566-294-7.ch005

Van Harmelen, M. (2006, July). Personal Learning Environments. In ICALT (Vol. 6, pp. 815-816). Retrieved from http://wiki.ties.k12.mn.us/file/view/PLEs_draft.pdf/282847312/PLEs_draft.pdf

Verpoorten, D., Glahn, C., Kravcik, M., Ternier, S., \& Specht, M. (2009). Personalisation of learning in virtual learning environments. In U. Cress, V. Dimitrova, \& M. Specht (Eds.), Learning in the synergy of multiple disciplines (pp. 52-66). Springer Berlin Heidelberg. Retrieved from http://dspace.learningnetworks.org/bitstream/1820/2023/1/paper_169.pdf

Corresponding author: Zaffar Ahmed Shaikh, zashaikh@iba.edu.pk

Australasian Journal of Educational Technology ( 2014.

Please cite as: Ahmed Shaikh, Z., \& Ahmed Khoja, S. (2014). Personal learning environments and university teacher roles explored using Delphi. Australasian Journal of Educational Technology, 30(2), 202-226. 